\title{
日本金属学会における 男女共同参画の歩み
}

1999年に男女共同参画社会基本法が制定・施行され，21 世紀の日本最重要課題と位置付けられた ${ }^{(1)}$.この法律の中で

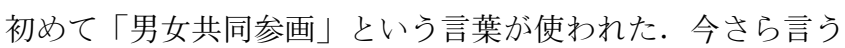
までもないが，「男女が互いにその人権を尊重しつつもその 責任を分かち合い, 性別に関わりなく, その個性と能力を十 分に発揮できる社会」という意味である. 2000年には, 男 女の均等な雇用の機会と待遇の確保などを掲げた男女共同参 画基本計画が決定され(2)，2001年には内閣府に男女共同参 画局が設置された：このような国の動きを背景に，2002年 には, 日本物理学会, 応用物理学会, 日本化学会などを中心 に, 理工学系の12学協会が集まり, 男女共同参画学協会連 絡会を発足させた $(2016 \text { 年現在, 53学協会が参加 })^{(3)}$.

\section{1. 日本金属学会における男女共同参画活動のはじまり}

日本金属学会 (以下, 金属学会) で男女共同参画活動が始屯 ったのは，このような社会の動きの中で，比較的早い2003 年のことである. 私が学会の男女共同参画に関わったきっか けは東北大の米永一郎先生からの 1 本の電話であった. 先 生は, 所属されている東北大や応用物理学会での取り組みに ついて説明され，金属学会でも男女共同参画活動のための WG を作りたいと説明された。個人的なことになるが，当 時, 私は 5 歳と 2 歳の子供を育児中で, 子育てをしながら 仕事をすることが許される社会を求めていたが，一方で，た だでさえ育児で仕事の時間が取れない中，男女共同参画活動 をしていて良いのか，そもそも，学会で取り組む男女共同参 画活動とは何か, という不安を抱いた. しかし, 当時物理学 会で男女共同参画活動をしていた NIMS の友人から話を聞 いていたこともあり, WG に参加することを決めた.

WG は2003年 8 月に理事会で承認され, 名古屋大 (当時)
の黒田光太郎先生を委員長として発足した. 当時の金属学会 は, 学会の座長, 分科会世話人, 編集委員, 理事, 役員など への女性の参加がなく, 辛ろうじて, まてりあ編集委員に女 性が加わり始めた程度であった(委員長: 深道和明東北大教 授). 第 1 期の WG メンバーは (当時所属, 敬称略), 米永一 郎 (東北大), 後藤 孝 (東北大), 今野豊彦 (大阪府大), 木村 薰(東大), 山下孝子 (川鉄技研), 楠美智子(ファインセラミ ックスセンター), 八木晃一 (NIMS), 吉原美和子 (横浜国 大), 加賀山朋子(熊大), 御手洗容子 (NIMS)であった. 2003年 9 月には, その前年に結成された男女共同参画学協 会連絡会にオブザーバー会員として参加申請し, 当時の連絡 会が行おうとしていた大型アンケートに参加した. その年 10月に開催された秋期学会で大型アンケートの回答を呼び かけたが, 回答したのは 271 人だけであった. 当時の会員数 が 7000 人であったことを考えると, 関心の低さが窥われ る. また, この学会期間中に, 第 1 回の WG が開催され た.ここで WG は終了し，10月12日(WG 開催翌日)から検 討委員会として活動を行うことになった.

\section{2. シンポジウム開催}

男女共同参画活動を知ってもらうため, また学会内でこの 活動の理解を得るために, むず取り組んだのはシンポジウム 開催による啓発活動であった. 2004年 3 月の春期大会最終 日の午後, 第 1 回の男女共同参画シンポジウムが「材料工 学教育研究集会」として東工大の百周年記念館で開催され た.この時の講演は, 「自然科学および科学技術系の学会. 協会に打ける男女共同参画への取り組み」小館香椎子先生 (日本女子大，男女共同参画学協会連絡会第 1 期委員長), 「科学技術分野に打ける女性研究者の能力発揮」都河明子先

* 物質・材料研究機構 構造材料研究拠点 : 副拠点長, 耐熱材料設計グループ グループリーダー（テ305-0047 つくば市千現 1-2-1) Strides of Gender Equality in JIM; Yoko Yamabe-Mitarai (Research Center for Structural Materials, Deputy Director, High Temperature Material Design Group, National Institute for Materials Science, Tsukuba)

Keywords: gender equality, network, symposium, nursery

2016年 5 月26日受理[doi:10.2320/materia.56.116] 
生 (東京医歯大)，「企業における男女共同参画の取り組み」 渡辺美代子氏(東芝)であった. 当時, 学協会連絡会で活発に 活動していた学会で活躍されていた方々である.小館先生に は, 自然科学分野で女性研究者が能力を発揮する重要性, 学 会でそれを支援することの大切さについてお話をいただき， 金属学会での男女共同参画活動に大きなエールを送っていた だいた．初回ということで，興味半分，冷やかし半分の聴衆 が多かったように感じたが，会場がいっぱいになるくらい聴 衆が集まった。シンポジウムの内容については，大型アンケ 一トの解析結果や, 日本物理学会 (以下, 物理学会) 奈良女子 大 $($ 松岡) や東北大 (米永)の取り組みに関する記事を追加し

表 1 開催したシンポジウム.

\begin{tabular}{|c|c|c|}
\hline 年 & 講師(所属‧当時) & 講演タイトル \\
\hline \multirow[t]{3}{*}{$\begin{array}{c}2004 \text { 年 } \\
3 \text { 月 }\end{array}$} & 小館香椎子 (日本女子大) & $\begin{array}{l}\text { 自然科学および科学技術系の } \\
\text { 学会・会に技ける男女共同 } \\
\text { 参画への組み }\end{array}$ \\
\hline & 都河明子(東京医歯大) & $\begin{array}{l}\text { 科学技術分野における女性研 } \\
\text { 究者の能力発揮 }\end{array}$ \\
\hline & 渡辺美代子(東芝) & $\begin{array}{l}\text { 企業における男女共同参画の } \\
\text { 取り組み }\end{array}$ \\
\hline \multirow[t]{4}{*}{$\begin{array}{c}2004 \text { 年 } \\
9 \text { 月 }\end{array}$} & 今野豊彦(大阪府大) & $\begin{array}{l}\text { 男女共同参画に関する学協会 } \\
\text { アンケート結果について }\end{array}$ \\
\hline & 御手洗容子(物材機構) & $\begin{array}{l}\text { 金属学会に抒ける男女共同参 } \\
\text { 晋に関するンケート告 }\end{array}$ \\
\hline & 松岡由貴(奈良女子大) & $\begin{array}{l}\text { 物理分野に抒ける男女共同参 } \\
\text { 画への取り組み }\end{array}$ \\
\hline & 米永一郎(東北大) & $\begin{array}{l}\text { 学会期間中の保育室設置に関 } \\
\text { す検討 }\end{array}$ \\
\hline \multirow[t]{3}{*}{$\begin{array}{c}2005 \text { 年 } \\
3 \text { 月 }\end{array}$} & 大坪久子(東大） & $\begin{array}{l}\text { 世代を超えた連携が成功をも } \\
\text { たらし物学 } \\
\text { 会・年回保育室ことをはじ分 こと }\end{array}$ \\
\hline & 束村博子(名古屋大) & $\begin{array}{l}\text { 名古屋大学に挄ける育児支援 } \\
\text { 取り組み心学内保育所設直 } \\
\text { 活動を心に一 }\end{array}$ \\
\hline & 松岡由貴(奈良女子大) & $\begin{array}{l}\text { 物理学会に抒ける託児室設置 } \\
\text { 抢よひ営柷 }\end{array}$ \\
\hline \multirow[t]{6}{*}{$\begin{array}{l}2006 \text { 年 } \\
9 \text { 月 }\end{array}$} & 田中龍彦委員長 & $\begin{array}{l}\text { 是本鉄鋼協会男女共同参画準 } \\
\text { 備会活動紹 }\end{array}$ \\
\hline & 黒田光太郎委員長 & $\begin{array}{l}\text { 莡本金属頱会男女共同参画委 } \\
\text { 紹 }\end{array}$ \\
\hline & $\begin{array}{l}\text { 株式会社神戸製鋼所 人事 } \\
\text { 労政部 松尾当詊長 }\end{array}$ & $\begin{array}{l}\text { 神戸成功に抢ける男女共同参 } \\
\text { 画活動 }\end{array}$ \\
\hline & 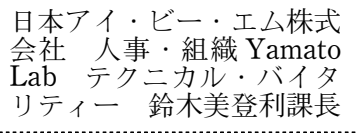 & $\begin{array}{l}\text { 日本アイービーエム社取り組 } \\
\text { み-女性社員活用のためのプ } \\
\text { ログラム }\end{array}$ \\
\hline & $\begin{array}{l}\text { 株式会社リコー 人事本部 } \\
\text { 人材登部国際人事グルー } \\
\text { プ 小谷美樹マージャー }\end{array}$ & $\begin{array}{l}\text { リコーのジェンダーフリー推 } \\
\text { 進活動 }\end{array}$ \\
\hline & $\begin{array}{l}\text { 奈永女子学 理学部物理 } \\
\text { 程貴 }\end{array}$ & $\begin{array}{l}\text { 生涯にわたる宏性研究者共助 } \\
\text { シテムの構筑 }\end{array}$ \\
\hline \multirow[t]{2}{*}{$\begin{array}{c}2008 \text { 年 } \\
3 \text { 月 }\end{array}$} & $\begin{array}{l}\text { 日本アイ·ビー·エム株式 } \\
\text { 会社 板倉真由美氏 }\end{array}$ & $\begin{array}{l}\text { 女性技術者育成の取り組み一ティー } \\
\text { 施策とコミュニティ }\end{array}$ \\
\hline & 産総研＼cjkstart澤田美智子氏 & $\begin{array}{l}\text { 女性研究者育成における独法 } \\
\text { 研究所の役割 }\end{array}$ \\
\hline
\end{tabular}

て，まてりあで小特集として紹介した ${ }^{(4)}$.2004年春期大会 で第 1 回シンポジウムを開催した後も，男女共同参画とい う概念を学会内で広げるため，2004年から2008年の間に 5 回のシンポジウムを開催している(表 1).2004年秋には秋田 大で第 2 回シンポジウムを開催し, 第 1 回大型アンケート の報告(米永), 金属学会の取り組み(御手洗), 物理分野での 取り組み(松岡), 託児室に関する検討 (米永)といった金属学 会内での取り組みを紹介した。第 3 回シンポジウムは2005 年 3 月, 横浜国立大で「日本分子生物学会の取り組み」（東 大 $\cdot$ 大坪久子先生), 名古屋大での取り組久 (名古屋大 ·束村 博子先生, 当時男女共同参画室長), 物理学会における託児 室運営 (松岡) と他学会, 大学での託児室の取り組みを紹介 し，学会内での託児室設置が必要であることを示し，この時 の理事会で託児室設置が承認された.

\section{3. 大会期間中託児室設置}

次に取り組んだのは，育児中の会員が講演大会に参加しや すい環境を作るための大会期間中の託児室設置であった。こ れは当時, 男女共同参画活動を行っていた学会がまず取り組 んでいたことであった．2004年秋期大会中に託児室に関す るシンポジウムを行い, 他学会や大学での託児室設置や利用 状況, 託児室設置のノウハウ, 賛成派の意見(子供がいても 学会に参加したい, 若い人の励ましになる), 反対派の意見 (学会として子供の面倒を見る必要があるか, 大会会場でな ぜ子供が保育されなければならないのか，会場に子供など邪 魔なだけではないか)などが示され，託児室設置の意味を委 員の中で明確化し, 設置に伴う問題点の対応などについて議 論した。他学会で託児室設置活動をしていた人たちからは, 子育てをしながら研究・学会活動をすることへの学会会員の 理解の低さが託児室設置のハードルになるため, 設置の必要 性や学会にとってのメリットについてしっかり示すようにア ドバイスをされた，この頃，物理学会にも所属していた松岡 先生 (奈良女子大, 現 ·金属学会男女共同参画委員会副委員 長)に，検討委員会委員となっていただき物理学会での託児 室設置について情報をいただいたのは大変心強かった，そん な中，第 0 分科から分科会活動への敃誘いがあり，分科会 で大会期間中の託児室設置について理解を得るために引き受 けた。

2005年春期大会中の分科会で決死の覚悟で託児室の必要 性を説いたが，予想に反して特に反対意見もなく，あっさり と承認された．大会での託児室，という概念に違和感を感じ ている委員はいたようたが，今の世の中はそういう動きなの だから認めざるを得ないというようなムードがあったように 思う. その後に開催された理事会でも承認され，2005年， 広島大学で開催された秋期大会での第 1 回託児室設置に向 けた準備が始まった。この時, 物理学会での経験がある松岡 先生からいただいたノウハウが大いに役立った．子連れで大 会に参加するということが一体どういうことなのかを理解す るために，まずは自分で利用することにした．私の他にもう 
一人利用者がいたが，夫婦で大会に参加しており，当たり前 のことながら，夫婦で大会活動に参加する場合には託児室は 大いに役に立つことに気がついた。託児室を利用した時，上 の子が 7 歳, 下の子が 4 歳であった. 子連れで大変だった ことは, 余計にかかる交通費, 宿泊費, 夜の交流会に参加で きないこと，荷物が多いことなどを感じたが，それよりも， 出張中にも子供と一緒にいられる安心感というメリットの方 が大きかった．大会会場内に子供がいるため，昼休みに子供 の様子を見に行くことができたのは私自身が安心できたし， 子供も私の顔を見て安心して遊んで抢り, また大変楽しかっ たのか，4歳の下の子がしばらく覚えていて，「またあそこ に行きたい」と言ったほどだ. 利用してみて, 託児室は育児 中の研究者・エンジニアには大変ありがたい設備であると感 じた。関東開催の春期大会も合わせて私はこれまでに 3 回 利用した．託児室の利用は図 1 に示すように，それほど多く ないし, 増加もしていない. 利用者が 0 の時もある.これ は，育児人口が少ないこともあるし，子供を連れて来られる 年齢幅が小さいこともある。 0,1 歳児は，一人で歩けず，体 調管理も難しいことから, 連れて歩くことがそもそも難しい. 7 歳をすぎると小学校を休ませなければならず，利用がしに くくなる．そうすると，3〜6歳くらいの間が最適利用期間 となる.このような理由もあり, 利用者数が 0 であること もあったが，それでも希望者が利用できるように託児室の設 置は毎回行ってきた. 申し込久期間中に申し込みが無い場合 は，託児室の設置はキャンセルされるため，費用は発生しな い. 年齢以外に利用しにくい理由があってはいけないため, 利用しやすい制度作りも行っている。これまで, 託児室利用 料金は 1 時間 800 円の個人負担であったため，利用金額を下 げる検討を行い，2016年秋の大会から，1 日1500～2000円 となっている.

\section{4. 鉄鋼協会との連携}

2006年になると日本鉄鋼協会 (以下, 鉄鋼協会)でも男女 共同参画委員会準備会が発足する. 東京理科大の田中龍彦先 生を委員長として，2006年春期大会では，女性研究者の集

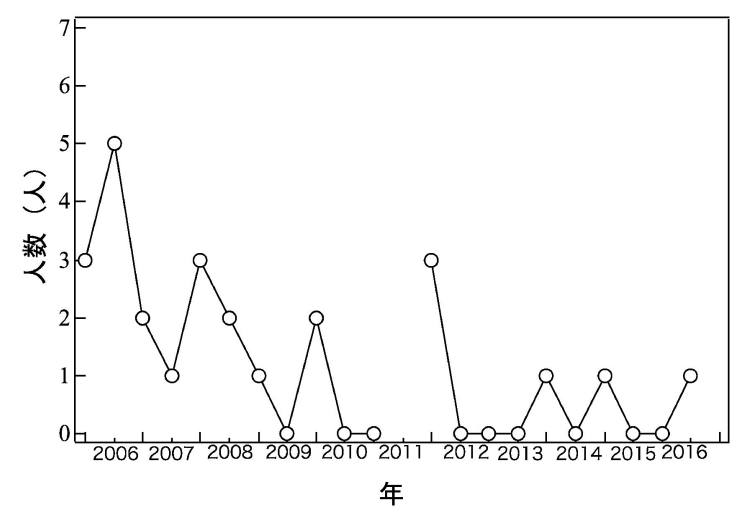

図 1 託児室利用人数の推移.
いを開催し，企業，大学，独法での女性研究者・技術者の現 状などを情報収集・意見交換した。また，2006年秋期大会 では，金属学会，鉄鋼協会とで合同シンポジウムを開催し た。「男女共同参画の取り組み一魅力ある職場組織作り一」 と題して，鉄鋼協会男女共同参画準備会 - 田中委員長，金属 学会男女共同参画委員会・黒田委員長，株式会社神戸製鋼所 人事労政部担当課長松尾健志氏, 日本アイ・ビー・エム株式 会社開発製造人事テクニカルバイタリティー課長・鈴木美登 利氏，株式会社リコー人事本部人材開発部国際人事グループ マネージャー・小谷美樹氏, 奈良女子大学・松岡由貴先生を パネリストとして，パネルディスカッションを行った.

2007 年 3 月に金属学会と鉄鋼協会の合同委員会が発足 し，共同で行えるような託児室の設置，イベント開催などは 協力し合うことを決めた. また, 早速, 会員への情報発信の ため, 男女共同参画委員会の HP を作成し (5), 男女共同参画 に関わる意見交換のためのメーリングリスト $(\mathrm{ML}) を$ 作成し た．MLではあまり活発な情報交換ができなかったため, 2015年秋から facebook を立ち上げた。（男女共同参画に関 する情報交換グループ(金属学会・鉄鋼協会)，兵庫県立大· 三浦永理先生担当)。そこでは男女共同参画に関する記事な ぞを投稿して，活発に情報交換をしている.

\section{5. 男女共同参画学協会連絡会}

始めに書いたように，男女共同参画学協会連絡会は2002 年に結成され，金属学会はオブザーバー学会として2003年 から参加している．2003年に参加学協会の会員を対象に大 型アンケートを行い, 回答者数19291人という膨大なデータ を集めた ${ }^{(6)}$.これにより，科学分野における女性研究者・技 術者の境遇, 問題点を明確化し, 女性研究者・技術者が抱え る問題を解決するための提言を各政府機関に提出するなど活 発な活動をし，これがその後の女性研究者支援のための振興 調整費プロジェクトなどにつながっていく．金属学会は 2003年に開催された第 1 回シンポジウムから参加し，これ らの活動に賛同してきた。2004年第 2 回，2006年第 4 回シ ンポジウムでは WG 活動も行い, シンポジウムの企画を支 えた。 2007 年には次世代の科学人口を増やすため, また, 女性が科学分野へ進学することを応援するため, 女子高生を 対象とした夏の学校を開催した（後に対象を中学生にも広 げ，女子中高生夏の学校となった.). 2 泊 3 日で埼玉県の女 性教育会館に宿泊し, 理系分野に進学した女子大生と共に学 会が提供する実験講座やポスター発表に参加したり，科学分 野で仕事をしている人のキャリア形成に関する講演を聴き, 科学への興味を誘う企画である．金属学会も鉄鋼協会ととも に参加し，ポスターを隣同士に並べ，鉄鋼協会は種類の異な る鋼を曲げさせることによって強度が違うことを体験させ， 金属学会は，金属当てクイズ，形状記憶合金，熱電変換材料 （東大・木村薰先生）の実験などを行った．それ以降，毎年夏 の学校には参加している．2008年からは 2 時間程度の実験 講座も担当し，金属の加工熱処理実験や低融点合金を用いた 


\section{6. 男女共同参画委員会}

図 2 男女共同参画委員会のロゴ.

メダル作りなどを行っている．2015年には生体材料の実験 も加わり, 関大 · 上田正人先生による $\mathrm{Ti}$ の陽極酸化, 陽極 酸化後の Tiに吸着させたたんぱく質をたんぱく質検出キッ トで検出する，という新しい実験も加わった ${ }^{(7)}$ 。また関西で 行われている同様のイベント, 関西科学塾にも金属学会, 鉄 鋼協会は共に協力団体として加わっており，実験講座のサポ ートも行なっている.

\section{7. 合同委員会ロゴ作り}

2009年には，合同委員会のロゴを作成したＮIMSの大 出真知子委員の配偶者である山崎壮氏 (2012年ランチョンミ 一ティング講師)によるデザィンで，男女で協力して社会を 作っていくイメージである(図 2).これ以降，合同委員会と してポスターやチラシを作成するときには，必ずこのロゴを 使うようにしている.

\section{8. ランチョンミーティング}

2009年春期大会から，ランチョンミーティングを開始し た（表 2). 大会 3 日目のお昼休みを利用して，（男女問わず） 学生向けのキャリア紹介講演を行っている. 先着 30 名に弁 当を無料配布し，金属材料を勉強して様々な分野で仕事をし ている人達に仕事や家庭との両立について講演をして頂いて いる. TMSの Young Leaderにアメリカの女性研究者の状 況を講演してもらったこともあり，この時は外国人学生も参 加して，ちょっとした国際会議のような雲囲気となった。こ れまで 2 人の講演者に㹉願いしていたが，十分な議論がで きないため，2016年春のランチョンミーティングでは講演 者を 1 人にし，その後に質疑の時間を長めに設けた。 ラン チョンミーティング終了後にも何人かの参加者が残り, 講演 者としばらく話をしていたため，このような交流が若い世代 の会員を励ましてくれることを実感した。

\section{9. 女性会員のネットワーク作り}

2011年秋からは，お昼休みを利用した女性会員の集いを 開催している。こちらは，参加者が自分で㡺食を持参し，そ れを食べながら交流するというものだ．特に話題は決めず, 集まったメンバーが自己紹介をして，気ままに話をしたり， 時にはある話題について議論したりする．ランチョンミーテ ィングもつどいも昼休みという時間制限があり，昼前後に自 分の発表や座長があると慌ただしく，ゆっくり話ができな い。そこで 2014 年から，春期大会時には，インフォーマル 交流会も行っている。このような活動を通じて女性会員のネ
表 2 ランチョンミーティングリスト.

\begin{tabular}{|c|c|c|}
\hline 年 & 講師 (所属 · 当時) & 講演タイトル \\
\hline \multirow[t]{2}{*}{2009} & $\begin{array}{l}\text { 梅津理恵 (東北大学多元物 } \\
\text { 質科学研究所·助教) }\end{array}$ & 大学における女性研究者 \\
\hline & $\begin{array}{l}\text { 山下孝子 (JFE スチール株 } \\
\text { 式会社 スチール研究所· } \\
\text { 主任研究員) }\end{array}$ & $\begin{array}{l}\text { 企業に敃構築 } \\
\text { ヤリ性採用変遷とキ }\end{array}$ \\
\hline \multirow[t]{2}{*}{2010} & $\begin{array}{l}\text { 宮島雅史 (ボッシュ株式会 } \\
\text { 社・デニカルセンターマ } \\
\text { ネージャー) }\end{array}$ & $\begin{array}{l}\text { 技術調査と技術移転の研究, ド } \\
\text { イツのこうを分るための独語 } \\
\text { 学習の毎日 }\end{array}$ \\
\hline & $\begin{array}{l}\text { 齋藤規子 (株式会社 IHI } \\
\text { 電力事業部 } \\
\text { 電力保守技術 } \\
\text { 課長) }\end{array}$ & 気負わず，あせらず，自分らし \\
\hline
\end{tabular}

2012 山崎 壮(アルプス電気株 研究者を伴侶にするということ 式会社)

芹沢 愛 (大阪大学マテリ オークリッジ国立研究所にて一 アル生産科学専攻）予メリカ流研究スタイル，異文 化に触れて

2013 金子美智代 (トヨタ自動車 解析に魅せられて 株式会社

久布白圭司(株式会社 IHI) 我が家の食卓〜妻の好物は，焼 き豚 つ

2014 Michele Manuel, Univ. of Current situation of female Florida researchers in USA

吉原美知子(横浜国立大学) 第 3 回男女共同参画大型アン ケート報告

2015 宮下直子(エイチ・シー・ Strength as being a Female スタルク株式会社) Workforce in Technical FieldPersonal Point of View

Qizhen Li (Washington State Women Scientists and Engineers University) in USA

2016 中田英子(旭硝子株式会社 出産が什事に与えた advantage 生産技術センター) 〜治金を軸に金属の外を歩く〜

ットワークを形成することにより，女性会員が金属材料の分 野で活躍し，学会でも活発に活動していければと思う.

\section{0. 役職比率調査}

男女共同参画活動を始めた2003年頃，金属学会の主要な 役職には女性がほとんぞいなかった。 その後, 男女共同参画 学協会連絡会の調査もあり, 2 年に 1 回, 役職比率調査を行 っている. 理事や委員会の委員長などの役職にどのくらい女 性が就いているかという調査である。図 3 に主要な役職の変 遷を示す。2005年には，男女共同参画委員会委員以外はほ とんぞ女性がおらず，特に，代議員，理事は 0 人であっ た。まず，まてりあの女性編集委員が増え，会誌・欧文誌編 集委員にも数人いたが，2015年の段階では 0 人になってい る. 一方，代議員は増加しており，2015年は 3 人，それに 対応して理事は 2013 年から 1 人になっている。この調査で は調べられていないが，委員会委員長は，私の記憶では，男 女共同参画委員会 (現·東北大 ·梅津理恵) 以外にはおらず, 2015年からまてりあ編集委員会の委員長にいる程度であ る.この他に，女性の活躍度を示す指標として座長やシンポ 


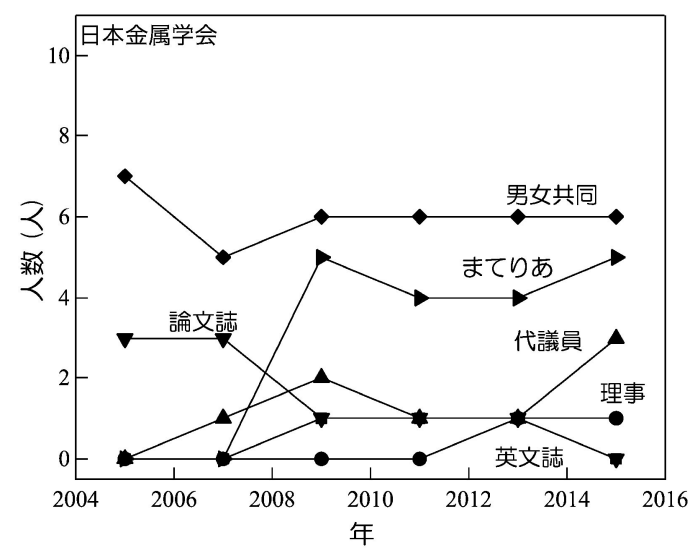

図 3 役職に占める女性の人数.

ジウムの企画者としてどのくらい女性が活躍しているか，と いうような調査も行っている.

\section{1. 終わりに}

様々な活動を行ってきたが，最近は，委員会活動を紹介す るために，「まてりあ」と「ふえらむ」に委員会活動報告を
掲載している．2017年秋には，委員会発足10周年記念のシ ンポジウムを開催予定である.

\section{文献}

(1) http://www.gender.go.jp/about_danjo/law/kihon/9906kihonhou. html

(2) http://www.gender.go.jp/about_danjo/basic_plans/

(3) http://www.djrenrakukai.org/index.html

（4）小特集「男女共同参画社会に向けて」まてりあ，43(2004), 895-930.

( 5 ) https://www.isij.or.jp/godo/isijjim/

(6) http://www.djrenrakukai.org/2003enquete/index.html

（7）上田正人：「女子中高生夏の学校2015」, まてりあ, 54(2015), 574.

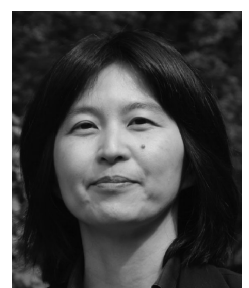

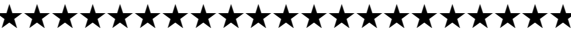
専門分野: 耐熱材料の開発

○現在耐熱 Ti 合金，高温形状記憶合金の開発を行つ ている. NIMS でも男女共同参画チームチーム長 として振興調整費「女性研究者支援モデル育成事 業」プロジェクトに携わった。その後, NIMS 男女共同参画デザイン室アドバイザーとして NIMS 内の制度改革や男女共同参画活動を行った。

御手洗容子 